\title{
GROWTH AND YIELD OF ONION (Allium ascalonicum L.) AGAINST VARIOUS CONCENTRATIONS OF LIQUID ORGANIC FERTILIZER
}

\author{
Sri Lestari Galagi ${ }^{1)}$, Aiyen $^{2)}$, Muhammad Anshar Pasigai ${ }^{2)}$ \\ 1) Agrotechnology Study Program, Faculty of Agriculture, Tadulako University., Palu \\ ${ }^{2)}$ Faculty of Agriculture, Tadulako University, Palu \\ Jl. Soekarno-Hatta Km 9, Tondo-Palu 94118, Sulawesi Tengah Telp. 0451-429738 \\ E-mail : srilestarigalagi@gmail.com, E-mail : aiyenb@ hotmail.com, E-mail : apasigai@yahoo.com
}

\begin{abstract}
Onion (Allium ascolanicum L.) is not only popular as cooking spices in Indonesia but also throughout the world. Onion that has high economic value, has its own attraction to be cultivated by farmers. However, farmers often face some problems in onion farming. Problems were faced by farmers related to social economic conditions both internal, external and natural conditions. Fertilizer application for onion can use inorganic and organic fertilizer materials. The use of inorganic fertilizers without the addition of organic fertilizers over a long period of time, suspected to cause a decrease in soil physical and chemical capabilities, with the application of solid and liquid organic fertilizer is predicted to be more effective because the elements are more than one element. The use of fertilizers and organic matter through soil is often inefficient because of the fixation by soil particles. Liquid fertilizers administered overcome gapnutrients during growth. Herbafarm liquid organic fertilizer is a type of liquid fertilizer released by PT. Sidomuncul herbafarm which contains bio protectant, processed from by products of medicinal products made from raw medicinal plants and spices. Herbafarm contains macro and micro nutrients and also organic compounds that are essential for the growth and development of plants. This research was conducted in Sidera village, Biromaru sub-district, Sigi regency, Central Sulawesi Province. This study used a Randomized Block Design consisting of 5 treatment levels: P0 $=$ control, P1 = 1 $\mathrm{ml} /$ liter of water, $\mathrm{P} 2=2 \mathrm{ml} /$ Liter of water, $\mathrm{P} 3=3 \mathrm{ml} /$ liter of water, and P4 $=4 \mathrm{ml} /$ liter of water. All treatments were repeated 4 (four) times, so that there were 5 treatments each time 4 replicates $=20$ experimental units. The results of this research were the best herbafarm POC on the treatment of $4 \mathrm{ml} /$ liter of water that was on the parameters of plant height of $33,56 \mathrm{~cm}$, leaves number as much as 30. 63 blades, total dry weight of crop $9.99 \mathrm{~g}$, number of tubers per family of 8.13 fruit, tuber diameter of $20.26 \mathrm{~mm}$, tuber length of $34.55 \mathrm{~mm}$, fresh tuber weight per family of $32.57 \mathrm{~g}$, tuber water content of $114.54 \mathrm{~g}$ and Weight of tuber per hectare 8.68 ton.ha-1.
\end{abstract}

Keywords : Growth, Onion, Liquid Organic Fertilizer, and Yield

\section{INTRODUCTION}

Onions (Allium ascolanicum L.) is not only popular as cooking spices in Indonesia but also in the whole world. Consumption of onion per capita Indonesia is increased year to year; recorded in 1981 consumption ranged from $1.65 \mathrm{~kg}$ per capita per year and in the year 2014 has become 2.49 per capita per year (Center for Agricultural Data \& Information, 2015).
According to Central Bureau of Statistics and Directorate General of Horticulture data (2016) the area of Onion harvest in Indonesia increased by almost $50 \%$ from 2012 (recorded 99,519 ha) to 2016 (recorded 148,343 ha) with production which also increased significantly from 1.233.984 to $14,338,094$ tons. However, in this report the change in planting area and the production rate of onion for Central Sulawesi Province is not increased positively. 
Onion, which has high economic value, has its own attraction to be cultivated by farmers. However, farmers often face some problems in onion farming. The problems faced are related to the internal socio-economic conditions (targets, risks, resource constraints) and external (inputoutput markets, institutional), and natural conditions that include climate (rainfall, temperature), biological (pests, diseases, weeds) and land (soil type, slope) (Koster 1990, Basuki \& Koster 1991, Nurmalinda et al. 1995, Adiyoga et al. 1997, Soetiarso et al. 1999 and Maryam 2006).

The use of inorganic fertilizers without the addition of organic fertilizers in a long period is suspected to lead the decline of soil physical and chemical abilities (Chen et al. 2009).

Application of organic fertilizers can be done in solid or liquid form. Liquid organic fertilizer is a solution of decomposition of organic materials derived from plant residues, animal waste and humans that contain more than one element (Hadisuwito, 2012), it can be a leaf fertilizer so it is predicted to be more effective. According to Sarief (1985) the provision of fertilizers and organic materials through the soil is often inefficient because of the fixation by soil particles. Liquid fertilizers are given to overcome nutritional deficiencies during growth.

Herbafarm POC is a type of liquid fertilizer containing bioprotectant, it is processed from by products of medicinal products made from raw medicinal plants and spices. Contains C-organic, N, P2O5, $\mathrm{K} 2 \mathrm{O}, \mathrm{Fe}, \mathrm{Mn}, \mathrm{Zn}, \mathrm{B}, \mathrm{Mo}, \mathrm{Cu}, \mathrm{Co}$, Azotobacter sp microorganisms, Azosprillium $\mathrm{sp}$, solvent bacteria $\mathrm{P}$, Lactobacillus $\mathrm{sp}$, Psedomonas sp, cellulotic bacteria, containing humic acid, sulfuric acid and plant hormones. Herbafarm contains macro and micro nutrients as well as organic compounds that are essential for plant growth and development of plants (Hasibuan, 2014).

Based on Hasibuan (2014) variance analysis result in cucumber plant, it is known that Herbafarm fertilizer $2 \mathrm{ml} /$ liters of positive water on plant height, number of saplings and rice production. In this study the function of Herbafarm POC is to improve productivity which is tested to the onion.

This study aimed to determine the best concentration of liquid organic fertilizer to support the growth and yield of onion production. The benefit of this research is to test industrial products and provide information about its effect to onion production.

\section{RESEARCH METHODS}

This research was conducted at Sigi Biromaru district Sigi Regency, Central Sulawesi Province. This research was conducted on January until March 2017.

The tools used in this research were hand tractor, hoe, machet, plow, ruler, cutter, analytical scales, oven, digital camera, handsprayer, and stationery. Materials used in this research were onion seed (Brebes variety), liquid organic fertilizer (Herbafarm), Fungicide Solution (Dithane-M45), endure insecticide and ayuna fungicide.

This research used Randomized Block Design (RBD) consisting of 5 treatment levels: $\mathrm{P} 0=$ control $(1$ liter of water), $\mathrm{P} 1=1 \mathrm{ml} \mathrm{POC/liter} \mathrm{of} \mathrm{water,} \mathrm{P} 2=2$ $\mathrm{ml} \mathrm{POC/liter} \mathrm{of} \mathrm{water,} \mathrm{P} 3=3 \mathrm{ml} \mathrm{POC} /$ liter of water, and $\mathrm{P} 4=4 \mathrm{ml} \mathrm{POC} /$ liter of water. All treatments were repeated 4 (four) times, so that there were 5 treatments every 4 replicates $=20$ experimental units.

Research Implementation. The implementation of this research included some stages among others : seed preparation, land preparation, planting, treatment applications, maintenance, and harvesting.

Seed Preparation. The ready-to-plant onion tubers were healthy tubers and had been stored for 2-6 months, at which time the tuber buds had begun to grow and have a high growing power.

Land Preparation. Preparation begun with site measurement and continued by tillaging with cleaning up the remnants of previous 
vegetation and land hijacking, then second hijacking and flattened by handtractor and hoe. Then done by making experimental plot in the form of beds with $255 \mathrm{~cm} \times 105$ $\mathrm{cm} \times 25 \mathrm{~cm}$ size and trance with distance of $40 \mathrm{~cm}$

Planting. Onion planting was first sorted by selecting solid and healthy tubers. Tubers were cut into $1 / 3$ part on the top before planting to facilitate germination and the sprouts became more uniform. Before planting the seeds were inserted into the fungicide solution (Dithane-M45) with a dosage of $10 \mathrm{~g} / 10 \mathrm{~kg}$ of tubers for 10 minutes, after that, theycan be dried up. Tuber planted with $15 \mathrm{~cm}$ x $15 \mathrm{~cm}$ space . Each hole was planted with a tuber, the tubers planted in an upright position and $2 / 3$ immersed in the soil and there were 119 number of plants per plot. Planting done in the morning until evening

Treatment Application. To determine the effect of Organic Liquid Fertilizer (Herbafarm) on the growth of onion, POC was administered 5 times every 7 days (7, 14, 21, 28 and 35) with concentration of $\mathrm{P0}=$ without spraying Herbafarm POC (Control), P1 = $2 \mathrm{ml} \mathrm{POC} /$ liter of water, $\mathrm{P} 2=2 \mathrm{ml} \mathrm{POC} /$ liter of water, $\mathrm{P} 3=3 \mathrm{ml}$ $\mathrm{POC} /$ liter of water and $\mathrm{P} 4=4 \mathrm{ml} \mathrm{POC} /$ liter of water.

Maintenance. One of the important steps in onion cultivation is Maintenance. If the plants are poorly maintained then optimal production is expected to be difficult to achieve. Plant maintenance activities include:

Watering. All plants need water for their survival. onion requires considerable water during growth and tuber formation. However, it should also be remembered that onion does not like too much water or the exceeding moist and muddy soil. This tuber will easily rot. Watering is done by inundating the water around the bed called "leb system", in this system the water level in the ditch is raised so that the water can seep and wet the onion rooting areas. However, water should be maintained so that the water does not induate the bed surface so that the tubers rot. After the watering has been complete, the trench is drained again. The provision of water is adapted to soil conditions and crop needs. Watering is done every day since planting, morning or evening. Watering is stopped 3-5 days before harvest for tubers not easily rot (Rahayu and Berlian, 2006).

Stitching. Stiching will be done if there are plants that die and do not grow or the growth is not normal until the age of 7 days after planting by replacing the rot or dead with a healthy tuber.

Control of Pests and Diseases. Control of pests and diseases using insecticides $1 \mathrm{~m} /$ liter Endur water and $1 \mathrm{~m} / \mathrm{liter}$ fungicide Ayuna $1 \mathrm{ml} /$ liter water that is often used by farmers in the region. The intensity of pest and disease control is adjusted to the condition and level of attack.

Harvest. Onion will be harvested after the age is quite old, ie at age of 70 days after planting. Onion is harvested after visible signs such as the leaves that have fallen or the neck stem soft, the plant falls and leaves become yellow. Harvesting is carried out when the soil is dry and the weather is sunny to avoid the attack of tuber rot when tubers are stored.

\section{Observation Parameters \\ Growth Components.}

Plant Height (cm). ie measuring from the base of the leaf to the longest end of the leaf, at age 20,30, 40 and 50 HST. taken from four sample plants, the measurements were done using a ruler.

Number of Leaves (Blade). Was observed during growth by counting the number of perfectly formed leaves at 20,30, 40, and 50 HST. taken from four sample plants.

Total Dry Weight Per Family. weighing the plant part which includes root, canopy and leaf is obtained from two crop samples which are harvested at 20,30, 40, and 50 HST. dry weight of the plant in weigh after 
the oven for $2 \times 24$ hours at a temperature of $800 \mathrm{C}$.

\section{Output Component and Quality.} Number of Tubers Per Family (Fruit). Calculated after the harvest had been done by counting the number of tubers formed in each clump.

Tuber Length (mm). Measured at harvest time, using a sliding range, an average of 10 tubers

Tuber Diameter. measured from an average of 10 tubers at harvest time, using a sliding anchor.

Weight of Fresh Tubers Per Family (g). freshly weighed and separated with stems and leaves.

Water Content of Tuber. Taken from 4 families of plants in each bed which were calculated using the following formula: Water content of tuber

$$
=\frac{d r y \text { weight }}{\text { fresh weig } h t} \times 100 \%
$$

Tuber Yield Per Hectare. (the conversion results from tile) was observed from the tiled plants that have been prepared of 40 families / plot, it can be converted by using the formula:

Tuber yield per hectare $=$

$$
\frac{\text { land } \text { area }}{\text { tile area }} \mathrm{X} \text { Tile weight }
$$

\section{RESULTS AND DISCUSSION}

\section{Results.}

Plant Height. The variance analysis result showed that treatment of Herbafarm POC on 20,30 and 40 HST onion had no significant effect on plant height, but at age of 50 HST had significant effect on plant height. Average plant height is presented in Table 1.

$\% \mathrm{BNJ}$ test results in table 1 shows the observation age of 50 HST with allocation of Herbafarm POC $4 \mathrm{ml} / \mathrm{liter}$ water yield highest average height of $33.56 \mathrm{~cm}$. POC $1 \mathrm{ml} /$ liter of water giving was very different with the provision of $4 \mathrm{ml} /$ liter of water. However, it was not significantly different from $2-3 \mathrm{ml} / \mathrm{liter}$ of water POC.

Table 1. Average Height of Some Brebes Onion Varieties $(\mathrm{cm})$ Brebes with Various Concentrations of Herbafarm POC 50 HST

\begin{tabular}{lc}
\hline \multirow{2}{*}{ Treatment } & $\begin{array}{c}\text { Average Height of } \\
\text { Plant }(\mathrm{cm})\end{array}$ \\
\cline { 2 - 2 } & $50 \mathrm{HST}$ \\
\hline P0 (control) & $27.50^{\mathrm{a}}$ \\
P1 (1 ml/liter water) & $30.66^{\mathrm{b}}$ \\
P2 (2 ml/liter water) & $31.19^{\mathrm{bc}}$ \\
P3 (3 ml/liter water) & $32.72^{\mathrm{bc}}$ \\
P4 (4 ml/liter water) & $33.56^{\mathrm{c}}$ \\
\hline BNJ 1\% & 2.47 \\
\hline
\end{tabular}

Description : The average value followed by the same letter in the same column, is not different at the $1 \% \mathrm{BNJ}$ test level.

Tabel 2. The Average Number of Leaves (Strands) of Brebes Onion Varieties with Various Herbafarm POC Concentrations at 30, 40 and 50 HST

\begin{tabular}{lccc}
\hline \multirow{2}{*}{ Treatment } & \multicolumn{3}{c}{$\begin{array}{c}\text { Average Number } \\
\text { of Leaves (Blade) }\end{array}$} \\
\cline { 2 - 4 } & 30 HST & 40 HST & 50 HST \\
\hline P0 (kontrol) & $16.00^{\mathrm{a}}$ & $17.88^{\mathrm{a}}$ & $18.38^{\mathrm{a}}$ \\
P1(1 ml/l & & & \\
water) & $21.38^{\mathrm{ab}}$ & $19.06^{\mathrm{ab}}$ & $17.50^{\mathrm{a}}$ \\
P2 (2 ml/l & & & \\
water) & $24.25^{\mathrm{b}}$ & $23.13^{\mathrm{b}}$ & $20.69^{\mathrm{ab}}$ \\
P3 (3 ml/l & & & \\
water) & $25.06^{\mathrm{b}}$ & $27.06^{\mathrm{b}}$ & $23.50^{\mathrm{b}}$ \\
P4 (4 ml/1 & & & \\
water) & $27.38^{\mathrm{b}}$ & $34.06^{\mathrm{c}}$ & $30.63^{\mathrm{c}}$ \\
\hline \multicolumn{1}{c}{ BNJ 1\% } & 8.10 & 4.48 & 4.15 \\
\hline
\end{tabular}

Description: The Average Value Followed by The Same Letter in the Same Column is Not Different at The $1 \%$ BNJ Test Level.

Leaf Amount. The results showed that the treatment of Herbafarm POC on 20 HST was not very significant effect on the number of leaves, while at 30, 40 and 50 
HST significantly affect the number of leaves. The average number of leaves is presented in Table 2.

The results of $1 \% \mathrm{BNJ}$ test in table 2 shows the observation age of 30,40 and $50 \mathrm{HST}$ giving Herbafarm POC $4 \mathrm{ml} / \mathrm{liter}$ water produce average highest number of leaves ie 27,38 34,06 and 30,63 blade. At the age of $30 \mathrm{HST}$ the treatment of $4 \mathrm{ml} /$ liter of water was not significantly different from the 1-3 $\mathrm{ml} /$ liter water treatment, but significantly different from the control. At the age of 40 HST the treatment of $4 \mathrm{ml} / \mathrm{liter}$ water was significantly different with the treatment of $2-3 \mathrm{ml} / \mathrm{liter}$ of water but was evident with the control. At the age of $50 \mathrm{HST}, 4 \mathrm{ml} /$ liter water treatment was significantly different with $3 \mathrm{ml} / \mathrm{liter}$ water but 2-3 ml/liter of water of Herbafarm POC had no significant effect. Compared with the control of $4 \mathrm{ml} / \mathrm{liter}$ water was very significant.

Total Dry Weight Per Plant. The results showed that the treatment of Herbafarm POC on 20 HST on leaf did not significantly affect the number of leaves, whereas at age 30 HST had significant effect, age 40 and 50 HST had a very significant effect on the number of leaves. The average number of leaves is presented in Table 3.

Result of $5 \%$ and $1 \%$ BNJ in Table 3 showed at observation age 30, 40 and 50 HST Herbafarm POC $4 \mathrm{ml} /$ liter water gave average highest dry weight of highest planting those were 2,38 5,89 and 9,99 g. The treatment of $4 \mathrm{ml} /$ liter water at 30,40 and 50 HST observations was significantly different with control, but 1-3 Hl/l water Herbafarm POC treatment had no significant effect on age 30, 40 and 50 HST.

Number of Tubers (Fruit) Per Family. The results of variance showed that the treatment of Herbafarm POC on onion had a very significant effect on the number of tubers (fruits) per hill. The average number of tubers (fruits) per family which was presented in Table 4 . The results of $1 \%$ BNJ test in table 4 shows that Herbafarm
POC $4 \mathrm{ml} /$ liter water gives the highest average number of tubers ie 8.13 fruit. Giving 3-4 $\mathrm{ml} /$ liter of water POC was not significantly different in plants. When compared with control and $1 \mathrm{ml} / \mathrm{liter}$ of water POC of $4 \mathrm{ml} /$ liter water had a very significant effect on the plant.

Table 3. Average Total Dry Weight Per Plant (g) of Brebes Onion Varieties with Various Herbafarm POC Concentrations at 30,40 and 50 HST

\begin{tabular}{lccc}
\hline \multirow{2}{*}{ Treatment } & \multicolumn{3}{c}{ Total Dry Weigh per Plant } \\
\cline { 2 - 4 } & $30 \mathrm{HST}$ & $40 \mathrm{HST}$ & $50 \mathrm{HST}$ \\
\hline P0 (kontrol) & $1.39^{\mathrm{a}}$ & $3.31^{\mathrm{a}}$ & $5.49^{\mathrm{a}}$ \\
P1 (1 ml/l & & & \\
water) & $1.96^{\mathrm{ab}}$ & $2.94^{\mathrm{a}}$ & $6.86^{\mathrm{ab}}$ \\
P2 $(2 \mathrm{ml} / \mathrm{l}$ & $1.85^{\mathrm{ab}}$ & $3.89^{\mathrm{ab}}$ & $7.18^{\mathrm{ab}}$ \\
water) & & & \\
P3 $(3 \mathrm{ml} / \mathrm{l}$ & $2.12^{\mathrm{ab}}$ & $4.09^{\mathrm{ab}}$ & $7.25^{\mathrm{ab}}$ \\
water) & & & \\
P4 (4 ml/l & $2.38^{\mathrm{b}}$ & $5.89^{\mathrm{b}}$ & $9.99^{\mathrm{b}}$ \\
water) & BNJ & BNJ1\% & $\mathrm{BNJ} 1 \%$ \\
& $5 \% 0.77$ & 2.20 & 3.64 \\
\hline
\end{tabular}

Description : The Average Value Followed by The Same Letter in The Same Column is Not Different at The $1 \%$ BNJ Test Level.

Table 4. Average Number of Tubers (Fruit) of Brebes Onion Varieties with Various Herbafarm POC Concentration

\begin{tabular}{lc}
\hline \multicolumn{1}{c}{ Treatment } & $\begin{array}{c}\text { Average Number of } \\
\text { Tubers (Fruit) Per Family }\end{array}$ \\
\hline P0 (control) & $4.50^{\mathrm{a}}$ \\
P1 (1 ml/l water) & $5.25^{\mathrm{a}}$ \\
P2 (2 ml/l water) & $6.31^{\mathrm{b}}$ \\
P3 (3 ml/l water) & $7.31^{\mathrm{bc}}$ \\
P4 (4 ml/l water) & $8.13^{\mathrm{c}}$ \\
\hline BNJ 1\% & 1.04 \\
\hline
\end{tabular}

Description: The Average Value Followed by The Same Letter in The Same Column, is Not Different at The $1 \%$ BNJ Test Level.

Tuber Diameter. The results of statistical analysis showed that the treatment of Herbafarm POC on onion had a very 
significant effect on tuber diameter. The average tuber diameter is presented in Table 5.

Table 5. Average Tuber Diameter (mm) of Brebes Onion Varieties with Various Concentrations of Herbafarm POC

\begin{tabular}{cc}
\hline Treatment & $\begin{array}{c}\text { The Average Diameter of } \\
\text { Tuber }(\mathrm{mm})\end{array}$ \\
\hline P0 (control) & $17.87^{\mathrm{a}}$ \\
P1 (1 ml/l water) & $18.93^{\mathrm{ab}}$ \\
P2 (2 ml/l water) & $18.85^{\mathrm{ab}}$ \\
P3 (3 ml/l water) & $20.13^{\mathrm{b}}$ \\
P4 (4 ml/l water) & $20.26^{\mathrm{b}}$ \\
\hline BNJ $1 \%$ & 1,60 \\
\hline
\end{tabular}

Description: The Average Value Followed by The Same Letter in the same column, is not different at the $1 \%$ $\mathrm{BNJ}$ test level.

The result of $1 \%$ BNJ test $1 \%$ in table 5 shows that Herbafarm POCof $4 \mathrm{ml} /$ liter water gave highest average diameter of tuber that was $20.26 \mathrm{~mm}$. When compared with the control treatment of 4 $\mathrm{ml} /$ liter water was significantly different in tuber diameter. In the treatment of 1-3 $\mathrm{ml} /$ liter of water POC effect was not much different on the average diameter of tubers.

Table 6. Average Length of Tuber (mm) of Brebes Onion Varieties with Various Herbafarm POC Concentration

\begin{tabular}{|c|c|}
\hline Treatment & $\begin{array}{c}\text { The Average Length of } \\
\text { Tuber (mm) }\end{array}$ \\
\hline P0 (kontrol) & $29.52^{\mathrm{a}}$ \\
\hline $\begin{array}{l}\mathrm{P} 1(1 \mathrm{ml} / \mathrm{l} \\
\text { water) }\end{array}$ & $30.63^{\mathrm{a}}$ \\
\hline $\begin{array}{l}\mathrm{P} 2(2 \mathrm{ml} / \mathrm{l} \\
\text { water })\end{array}$ & $35.38^{\mathrm{bc}}$ \\
\hline $\begin{array}{l}\mathrm{P} 3(3 \mathrm{ml} / \mathrm{l} \\
\text { water) }\end{array}$ & $38.61^{\mathrm{c}}$ \\
\hline $\begin{array}{l}\mathrm{P} 4(4 \mathrm{ml} / \mathrm{l} \\
\text { water) }\end{array}$ & $34.55^{\mathrm{b}}$ \\
\hline BNJ $1 \%$ & 4.44 \\
\hline
\end{tabular}

Description: The Average Value Followed by The Same Letter in The Same Column, is Not Different at The $1 \%$ BNJ Test Level.
Tabel 7. Average Weight of Fresh Tubers Per Clump (g) of Brebes Onion Varieties with Various Herbafarm POC Concentration

\begin{tabular}{cc}
\hline Treatment & $\begin{array}{c}\text { Average weight of fresh } \\
\text { bulbs per hill }(\mathrm{g}\end{array}$ \\
\hline P0 (control) & $17.11^{\mathrm{a}}$ \\
P1 (1 ml/l water) & $23.12^{\mathrm{ab}}$ \\
P2 (2 ml/l water) & $28.87^{\mathrm{ab}}$ \\
P3 (3 ml/l water) & $26.76^{\mathrm{ab}}$ \\
P4 (4 ml/l water) & $32.57^{\mathrm{b}}$ \\
\hline BNJ 1\% & 12.05 \\
\hline
\end{tabular}

Description: The Average Value Followed by The Same Letter in The Same Column, is Not Different at The 1\% BNJ Test Level.

The results of $1 \% \mathrm{BNJ}$ test $1 \%$ in table 6 shows that herbafarm POC of $3 \mathrm{ml} /$ liter water produced average length of highest tuber as long as $38.61 \mathrm{~mm}$. Treatment of 2-3 ml/liter of water was not significantly different from the average tuber length, when compared with control and administration of $1 \mathrm{ml} /$ liter of water 2-3 $\mathrm{ml}$, the liter of water was very significant on average tuber length.

Fresh Tuber Weight Per Family. The results of variance showed that the treatment of Herbafarm POC on onion had a very significant effect on the weight of fresh tubers per family. The average weight of fresh tuber per family is presented in Table 7.

The results of $1 \% \mathrm{BNJ}$ test in table 7 shows that Herbafarm POC of $4 \mathrm{ml} / \mathrm{liter}$ water produced average fresh weight of tuber per family ie $32.57 \mathrm{~g}$. Giving of 1-4 $\mathrm{ml} /$ liter of Herbafarm POC water did not differ significantly on average fresh weight of tubers. However, if compared with dick Herbafarm POC contrast significantly different on the average weight of fresh tuber.

Water Tuber Level. The results of variance showed that the treatment of Herbafarm POC on onion had a very significant effect on water content of tubers. Average tuber water content is presented in Table 8. 
Table 8. Average water content of (\%) red Brebes onion varieties tubers with various Herbafarm POC concentrations

\begin{tabular}{cc}
\hline Treatment & $\begin{array}{c}\text { Average Water Content of } \\
\text { Tuber }(\%) \text { Onion }\end{array}$ \\
\hline P0 (control) & $45.35^{\mathrm{a}}$ \\
P1 (1 ml/l water) & $63.21^{\mathrm{b}}$ \\
P2 (2 ml/l water) & $66.01^{\mathrm{b}}$ \\
P3 (3 ml/l water) & $68.42^{\mathrm{b}}$ \\
P4 (4 ml/l water) & $75.87^{\mathrm{b}}$ \\
\hline BNJ 1\% & 18.39 \\
\hline
\end{tabular}

Description: The Average Value Followed by The Same Letter In The Same Column, Is Not Different at $1 \%$ BNJ Test Level.

$1 \%$ BNJ test results in table 8 shows that the Herbafarm POC $4 \mathrm{ml} / \mathrm{liter}$ water produced average water content of the highest tuber ie $75.89 \%$. Compared with the control of $4 \mathrm{ml} /$ liter water was significantly different from the average tuber water content, but it was not significantly different with the 1-3 $\mathrm{ml} / \mathrm{liter}$ POC water treatment.

Results of tuber per hectare. The result of variance showed that the treatment of Herbafarm POC on onion had a very significant effect on tuber yield per hectare. The average weight of tiles per hectare is presented in Table 9.

Table 9. Average Yield of Tuber Per Hectare (ton) of Brebes Onion Varieties with Herbafarm POC Various Concentrations

\begin{tabular}{cc}
\hline \multicolumn{1}{c}{ Treatment } & $\begin{array}{c}\text { Average Yield of Tiles } \\
\text { Per Hectare (ton) }\end{array}$ \\
\hline P0 (control) & $5.37^{\mathrm{a}}$ \\
P1 (1 ml/l water) & $6.45^{\mathrm{ab}}$ \\
P2 (2 ml/l water) & $7.91^{\mathrm{b}}$ \\
P3 (3 ml/l water) & $8.16^{\mathrm{b}}$ \\
P4 (4 ml/l water) & $8.68^{\mathrm{b}}$ \\
\hline BNJ 1\% & 2.52 \\
\hline
\end{tabular}

Description: The Average Value Followed by The Same Letter in The Same Column, is Not Different at $1 \%$ BNJ Test Level.
The result of $1 \% \mathrm{BNJ}$ test in table 9 shows that the giving of Herbafarm POC $4 \mathrm{ml} /$ liter of water yields the highest weight average of 8.68 ton/hectare. When compared with the control treatment $4 \mathrm{ml} /$ liter water is significantly different on the average yield of tubers per hectare. When compared with 1-3 ml/liter Herbafarm POC water treatment did not have a significant effect on tuber yield per hectare. the other treatment P4 produces the highest average tiling weight.

\section{Discussion.}

Onion Growth. The results showed that the various Herbafarm POC treatments had an effect on all growth components of plant height, number of leaves, and total dry weight of crops. This was thought to be influenced by Herbafarm's cobalt organic fertilizer given to plants that are essential elements needed by plants in sufficient quantities. If one of these nutrients can not be fulfilled then the metabolism and growth of plants will be disturbed even cause death. Sufficient nutrient content in the soil as well as to be given in the form of cotton organic fertilizer will cause vegetative growth in shallot crops to be good. Plants require a primary nutrient such as NPK at the time of growth. Paulto et al. 1989 stated that the process of plant metabolism is determined by the availability of macro nutrient nutrients $\mathrm{N}, \mathrm{P}$ and $\mathrm{K}$ in a fairly balanced amount, either vegetative growth phase or generative growth phase.

Herbafarm liquid organic fertilizer has nutrient content and also microorganisms that can help provide nutrients in the soil so that nutrients needed by plants can be available sufficiently. Nitrogen is the main nutrient needed by plants because it can encourage the growth of plants such as roots, stems and leaves. The ability of this onion plant to grow due to nutrients in the soil and through the addition of doses of organic fertilizer cerb herbafarm so that $\mathrm{N}$ elements can be fulfilled and trigger plant growth. The role of rhizobium on plant growth is especially related to the availability of nitrogen for its host plants (Rahmawati, 2005). 
The liquid organic fertilizers given on onion provide sufficient nutrients and have microorganisms capable of providing nutrients already available in the soil such as azotobacter and azospirillum $s p$. Thus, it can absorb and can contribute to help the process of nutrient absorption from the soil so that the maximum role that supports the growth of onion plants. In addition Azospirillumsp., Azotobacter, and Pseudomonas are hydrocarbonoclastic bacteria that capable of degrading various types of hydrocarbons. The use of solvent $\mathrm{P}$ bacteria as biological fertilizer has advantages such as energy saving, not polluting the environment, able to help increase solubility of $\mathrm{P}$ absorbed, blocking the absorption of $\mathrm{P}$ fertilizer by absorbent elements and reducing toxicity of $\mathrm{Al} 3+, \mathrm{Fe} 3+$, and $\mathrm{Mn}$ to the plant on acid soil. In certain species this microb can spur plant growth because it produces ZPT and resist root pathogen penetration because it is able to colonize roots and produce antibiotic compounds (Setiawati 2003). Wu et al. (2005) added that the use of biological fertilizers does not only increase the nutrient levels of $2+$ nutrients in plants such as nitrogen $(\mathrm{N})$, phosphorus $(\mathrm{P})$, and potassium $(\mathrm{K})$, but also keep the organic and total $\mathrm{N}$ compounds in the soil.

Results of Onion Plant. The results showed that the treatment of various concentrations of herbafarm liquid organic fertilizer had significant effect on all the components of tubers, tuber length, tuber diameter, tuber fresh weight per family, tuber water content and tuber yield per hectare. Plants will be optimal if conditions are met such as the availability of sufficient nutrients and environmental factors accordingly. With the provision of liquid organic fertilizer herbafarm to supplement the content of macro and micro nutrients that are already available in the soil to be available sufficiently for onion, so the growth and productivity of the plant will run smoothly.
The content of $\mathrm{P}$ available in the soil as well as in Herbafarm POC serves as a source of energy in various metabolic reactions of plants plays an important role in increasing yields and giving much photosintat banayak that is distributed into the seeds. Tuber size and tuber quality in the vegetative and generative phases will be influenced by element $\mathrm{K}$, while $\mathrm{P}$ influences the formation and accelerates the interest (Novizan 2001).

Rahayu and Berlian (2004) said that onion requires macro nutrient and micro nutrient enough for the plant to grow optimally and produce high, the greater diameter of tubers produced, the more nutrients used for the growth of tubers. In addition to the nutrient content in Herbafarm fertilizer containing macro nutrients $(\mathrm{N}, \mathrm{P}$, $\mathrm{K}, \mathrm{C}$ and $\mathrm{Ca}$ ) and micro ( $\mathrm{Zn}, \mathrm{Cu}, \mathrm{Mn}, \mathrm{Co}$, $\mathrm{B}, \mathrm{Mo}, \mathrm{Fe}$ da $\mathrm{Co}$ ), the treatment of fertilizer through the leaves also contributes affect the growth and production of plants.

\section{CONCLUSION AND SUGGESTION}

\section{Conclusion.}

Based on the results above can be concluded that:

The best herbafarm POC effect on 3-4 $\mathrm{ml} /$ liter water treatment improves growth and yield when compared to control with $40 \%$ leaf number and $45 \%$ more tuber number than control. The administration of POCs is lower than 3-4 m/liter of water generally do not contribute significantly and positively to the observed parameters.

\section{Suggestion.}

Information on POC test results of onion shows 3-4 ml/liter can increase production. Research with the same treatment needs to be done on other plants, whereas the treatment $>4 \mathrm{ml} /$ liter of water needs to be done on the red onion to find out the maximum threshold of liquid fertilizer on onion crops. 


\section{BIBLIOGRAPHY}

Aldilas Meri, 2015. Pengaruh Pupuk Organik Cair terhadap Pertumbuhan dan Hasil Bawang Merah (Allium ascolanicum L.). Fakultas Pertanian. Universitas Tamansiswa. Padang.

Chen WC, Wang KR, XieXL. 2009 Effects on Distributions of Carbon and Nitrogen in a Reddish Paddy Soil Under Long-Term Different Fertilization Treatments. Chinese Journal of Soil Science 40: 523-528.

Gardner, T.P., R. B. Pearce dan R.L. Mitchell. 1992. Fisiologi Tanaman Budidaya. Penerbit Universitas Indonesia. Jakarta.

Hadisuwito, S. 2007. Membuat Pupuk Kompos Cair. PT. Agromedia Pustaka. Jakarta. 50 hal.

Hasibuan, Syafrizal. 2014. Respon Pemberian Konsentrasi Pupuk Herbafarm dan POC Keong Mas terhadap Pertumbuhan dan Produksi Tanaman Mentimun (Cucumis sativus L.). Sumatera Utara.

Hardjadi, S.S. 1990. Pengantar Agronomi. PT. Gramedia. Jakarta.

Laude, S. dan A. Hadid, 2007. Respon Tanaman Bawang Merah terhadap Pemberian Pupuk Organik Cair Lengkap. J. Agrisains 8 (3) : 140-146.

Lingga, P., dan Marsono. 2004. Petunjuk Penggunaan Pupuk. Penebar Swadaya. Jakarta.

Madauna S. Ichwan. 2009. Kajian Pupuk Organik Cair Lengkap Dosis Rendah pada Sistem Budidaya Tanpa Olah Tanah terhadap Pertumbuhan Gulma dan Hasil Jagung. Jurusan Budidaya. Pertanian Fakultas. Pertanian Universitas Tadulako. J. Agroland. 16 (1) : 24 - 32. Maret 2009.

Nasaruddin. 2010. Budidaya dan Beberapa Aspek Fisiologisnya. Fakultas Pertanian Universitas Hasanuddin dan Yayasan Forest Indonesia. Jakarta.

Novizan. 2001. Petunjuk Pemupukan yang Efektif. Agromedia pustaka. Jakarta.

Rahayu, E, dan Berlian, N. V.A, 2004. Bawang Merah. Penebar Swadaya, Jakarta, Hal 94. Gardner, P.F,. Pearce, B.R dan Mitchell, L.R. 1991. Fisiologi Tanaman Budidaya. Universitas Indonesia Press. Jakarta.

Rahmawati, N. 2005. Pemanfaatan Biofertilizer pada Pertanian Organik. Fakultas Pertanian Sumatera Utara.

Setiawati, C 2003. Peranan Bakteri terhadap Dinamika Fosfat. Unibraw. Malang.

Sutejo, M. M. 2002. Pupuk dan Cara Pemupukan. Rineke Cipta. Jakarta.

Paulton, J.E., J.T. Romeo and E.E. Conn,. 1989. Plan Nitrogen Metabolisme. Recent Advances in Phytochemistry. Vol. 23. New York. Plenum Pres.

Pusat Badan Statistik dan Direktorat Jenderal Hortikultr. 2016 pada lama http://www.pertanian.go.id/Data5tahun/HortiASEM2016(pdf)/Produksi\%20B.\%20Merah.pdf

Pusat Data \& Informasi Pertanian. 2015. Outlook Bawang Merah. http://epublikasi.setjen.pertanian.go.id/epublikasi/outlook/2015/Hortikultura/Outlook\%20Bawang\%2 0Merah\%202015/files/assets/common/downloads/Outlook\%20Bawang\%20Merah\%202015.pdf

Wu, SC, Cao, ZH, Cheung, KC \& Wong, MH 2005. 'Effects of Biofertilizer Containing N-Fixer, P and K Solubilizers and AM Fungi on Maize Gowth: A Greenhouse Trial', Geoderma. Vol. 125. pp. 155-66. 